\title{
A Numerical Study of the Flexural Behavior of Concrete Beams Reinforced with AFRP Bars
}

\author{
A. Buyukkaragoz,, a,1 I. Kalkan, ${ }^{\text {b,2 }}$ and J. H. Lee Le,3 $^{c, 3}$ \\ ${ }^{a}$ Gazi University, Ankara, Turkey \\ ${ }^{\mathrm{b}}$ Kirikkale University, Kirikkale, Turkey \\ ${ }^{c}$ Research \& Engineering Division, POSCO E\&C, Incheon, Korea \\ 1 akaragoz@kku.edu.tr \\ 2 ilkerkalkan@kku.edu.tr \\ 3 jonghan.lee@poscoenc.com
}

УДК 539.4

\section{Численное исследование изгибных характеристик железобетонных балок, упрочненных полимерными стержнями из армированных волокон}

\author{
А. Буюккарагоз ${ }^{\mathrm{a}}$ И. Калкан ${ }^{\sigma}$, Дж. Х. Ли \\ ${ }^{\text {a } У н и в е р с и т е т ~ Г а з и, ~ А н к а р а, ~ Т у р ц и я ~}$ \\ ${ }^{\sigma}$ Университет г. Кириккале, Турция \\ ${ }^{\text {в }}$ POSCO E\&C, Инчхон, Корея
}

Представлены результаты аналитических и численных исследований, иелью которых является определение изгибных характеристик железобетонных балок, упрочненных полимерныли стержнями из армированных волокон. C помощуью специильного метода конечных элементов, включающего различные элементы для процессов бетонирования и армирования, провели анализ железобетонных балок, армированных полимерныли стержнями. Для оченки характеристик прогиба под действием нагрузки и прогиба балки под действием рабочей нагрузки использовали два различных уравнения эффективного момента инерции. Значения прогиба железобетонных балок с полимерными стержнями под действием рабочей нагрузки, полученные конечноэлементным методом, хорошо сопоставляются со значениями из уравнений момента инерции. Численные значения разрушающего момента также хорошо согласуются с аналитическими значениями, полученными в результате применения модели зависимости деформации от напряжения для бетона. Для консервативной оценки прогиба представлень результаты численного анализа, которые почти не спрогнозировали внезапное уменьшение показателя жесткости при изгибе железобетонных балок с полимерными стержнями вследствие разрушения зашитного слоя бетона.

Ключевые слова: арамидное волокно, конечноэлементный анализ, бетон, армированный волокнитом, эффективное значение момента инерции, изгибная характеристика. 


\section{Notation}

$E_{f} \quad-$ elastic modulus of fiber-reinforced polymer (FRP)

$E_{s} \quad-$ elastic modulus of steel

$f_{c}^{\prime} \quad-$ cylinder compressive strength of concrete

$f_{r} \quad-$ modulus of rupture

$I_{c r} \quad-$ fully-cracked moment of inertia

$I_{e} \quad-\quad$ effective moment of inertia

$I_{g} \quad-$ gross moment of inertia

$M_{c r} \quad-$ cracking moment

$M_{\max }$ - maximum bending moment in the beam

$M_{u c 1}$ - ultimate moment estimate from rectangular stress block analysis

$M_{u c 2}$ - ultimate moment estimate from the adopted concrete stress-strain models

$M_{u f} \quad-$ ultimate moment estimate from finite element analysis (FEA)

$M_{u t} \quad$ - experimental ultimate moment

$\alpha_{b} \quad-$ bonding coefficient

$\rho \quad-$ longitudinal reinforcement ratio

$\rho_{b} \quad-$ balanced reinforcement ratio

Introduction. The noncorrosive, nonmagnetic, and nonconducting nature; high strength-to-weight ratio; and fatigue resistance make FRP materials a strong alternative to steel reinforcement. FRP reinforcement is commonly used in structures where the magnetic nature of steel reinforcement is a cause of concern, such as research facilities, magnetic resonance imaging rooms of health facilities, and magnetic levitation train facilities. FRP reinforcement is also preferred over steel reinforcement in concrete structures subjected to aggressive environments, such as coastal structures, infrastructure facilities, and bridge decks exposed to chlorides and deicing salts. In North America, several research projects have been launched to stimulate the use of FRP reinforcement in bridge decks to overcome the reinforcement corrosion problem. In the light of these projects, bridge decks containing FRP reinforcement were constructed in US and Canada in recent years [1-3]. Several developed countries have established their standards and regulations for FRP-reinforced concrete [4-6].

The comparatively high tensile strength and low elastic modulus of FRP bars cause serviceability limit states to be as critical as the ultimate limit states in the design of concrete beams reinforced with FRP bars. The present study mainly deals with the load-deflection behavior of FRP RC beams with the critical review of the literature devoted to the deflection response of FRP RC beams [7-15].

The gradual transition in the flexural response of a steel-reinforced concrete beam due to the formation and propagation of flexural cracks along the span is accounted for in ACI 318M-05 [16] by the use of the following effective moment of inertia $\left(I_{e}\right)$ equation:

$$
I_{e}=I_{g}\left[\frac{M_{c r}}{M_{\max }}\right]^{3}+I_{c r}\left[1-\left(\frac{M_{c r}}{M_{\max }}\right)^{3}\right] \leq I_{g},
$$


where $I_{g}$ and $I_{c r}$ are the gross and fully-cracked moments of inertia, respectively, $M_{c r}$ is the cracking moment, and $M_{\max }$ is the maximum bending moment in the beam.

Recent studies $[8,13]$ indicated that Eq. (1), which is originally an empirical equation developed by Branson [17] based on the test results of steel-reinforced concrete beams, overestimates the rigidities of FRP-reinforced concrete beams. ACI 440.1R-06 [4] provides the following effective moment of inertia equation for FRP-reinforced concrete beams by reducing the weight of the gross moment of inertia:

$$
I_{e}=\beta I_{g}\left[\frac{M_{c r}}{M_{\max }}\right]^{3}+I_{c r}\left[1-\left(\frac{M_{c r}}{M_{\max }}\right)^{3}\right] \leq I_{g},
$$

where $\beta$ is a coefficient accounting for the different bond properties and elastic modulus of FRP. ACI 440.1R-06 [4] gives the following equation for $\beta$ :

$$
\beta=\frac{1}{5}\left(\frac{\rho}{\rho_{b}}\right) \leq 1,
$$

where $\rho$ is the longitudinal reinforcement ratio and $\rho_{b}$ is the balanced reinforcement ratio.

Many studies in the literature aimed at determining an effective moment of inertia that yields deflection estimates in closest agreement with the experimental results. Gao et al. [9] proposed the following expression for $\beta$ in Eq. (2) based on their experimental results:

$$
\beta=\alpha_{b}\left(\frac{E_{f}}{E_{s}}+1\right)
$$

where $E_{f}$ and $E_{s}$ are the elastic moduli of FRP and steel, respectively, and $\alpha_{b}$ is a bond coefficient depending on the FRP material. Yost et al. [13] tested 48 GFRP RC beams made with normal-strength (NSC) and high-strength (HSC) concrete and proposed the following equation for $\alpha_{b}$ based on the linear regression analysis of their test results:

$$
\alpha_{b}=0.064 \frac{\rho}{\rho_{b}}+0.13
$$

Theriault and Benmokrane [10] and Masmoudi et al. [11] proposed a constant value of 0.6 for $\beta$ and found the agreement of Eq. (2) with $\beta=0.6$ with the experimental results. Different from these studies, Toutanji and Saafi [12] proposed that Eq. (1) can be modified for FRP RC beams by replacing the power 3 in the equation with an expression, which was obtained empirically from the results of experiments on GFRP RC beams, accounting for the elastic modulus of FRP and the reinforcement ratio. 
Bischoff $[18,19]$ established that Eq. (1) provides close estimates in reinforced concrete beams with $I_{g} / I_{c r}$ ratios smaller than 3 . Due to the low elastic moduli of FRP bars, $I_{g} / I_{c r}$ ratio reaches values much greater than 3 in FRP RC beams. Therefore, Eq. (1) significantly overestimates effective moments of inertia of FRP $\mathrm{RC}$ beams. By using the tension-stiffening model of the CEB-FIP Model Code [20], Bischoff [18] developed the following effective moment of inertia expression, which models the cracked portions of a beam and the uncracked portions between the cracked portions with springs in series:

$$
\frac{1}{I_{e}}=\frac{1}{I_{g}}\left[\frac{M_{c r}}{M_{\max }}\right]^{2}+\frac{1}{I_{c r}}\left[1-\left(\frac{M_{c r}}{M_{\max }}\right)^{2}\right] \geq \frac{1}{I_{g}} .
$$

Comparing with the previous test results [14], Bischoff and Scanlon [21] indicated that Eq. (6) closely estimates the flexural responses of FRP-reinforced concrete beams.

Thus, as an initial study, this research investigated the flexural performance of FRP RC beams using the finite element analysis (FEA) program ANSYS [22], which has scarcely been used in the field of civil engineering [23-33]. For this purpose, this study selected nine reinforced concrete beams tested by Rashid et al. [14]. The experimental and numerical (FEA) ultimate flexural moment capacities of the beams were compared with the analytical values obtained from the rectangular stress block approach and two different stress-strain models. The first model was proposed for HSC by Wee et al. [34] and the second one for NSC by Todeschini et al. [35]. The experimental and numerical load-deflection curves were also compared with the analytical curves obtained using the effective moment of inertia expressions of Bischoff [18], ACI 318M-05 [16], and ACI 440.1R-06 [4]. The numerical and analytical load-deflection curves were found to be in close agreement with the experimental ones at service load levels. This agreement was maintained up to the first peak in the load-deflection curve, corresponding to the crushing of cover concrete. Beyond the first peak, the numerical and analytical deflection estimates were found to remain on the unconservative side.

\section{Numerical Study.}

1.1. Analyzed Beams. In the present study, nine reinforced concrete beams constructed and tested by Rashid et al. [14] were analyzed. The specimens tested by Rashid et al. [14] were adopted in the numerical study mainly for the following reasons:

Rashid et al. [14] tested FRP RC beams with different flexural and shear reinforcement ratios. Consequently, numerical analyses of these beams were considered important in understanding the flexural behavior of FRP RC beams with varying amounts of reinforcement.

In their study, Rashid et al. [14] reported the measured material properties of concrete, steel, and aramid FRP (AFRP), which were used in the FE models of the specimens. Furthermore, the deflections and crack widths of the specimens along the course of loading were also presented in the study of Rashid et al. [14]. Consequently, the authors of the present study were able to compare the numerical results with the experimental results and this comparison yielded important conclusions. 
Each of the analyzed beams had a $150 \times 300 \mathrm{~mm}$ cross-section and a total length of $3.0 \mathrm{~m}$. The beams were subjected to third-point loading with a clear span of $2.4 \mathrm{~m}$. The reinforcement details of the specimens are illustrated in Fig. 1 and Table 1. As given in Table 1, all of the FRP RC specimens were over-reinforced as suggested by ACI 440.1R-06 [4]. Beam DS4T2 contained only steel reinforcement to serve as reference. Rashid et al. [14] reported that the beams DF2T1, DF3T1, and DF4T1 were tested to investigate the influence of longitudinal reinforcement ratio on the flexural behavior of FRP RC beams, while the tests on AF2T1 and DF2T1 provided information on the influence of concrete strength on the flexural behavior. Finally, by testing DF3T1, DF3T2, and DF3T3 in the program, Rashid et al. [14] aimed at investigating the influence of lateral reinforcement ratio on the flexural behavior of FRP RC beams.

T a b 1 e 1

Reinforcement Details of the Specimens

\begin{tabular}{|c|c|c|c|}
\hline \multirow{2}{*}{ Specimen } & \multicolumn{2}{|c|}{ Tensile reinforcement ratio (\%) } & \multirow{2}{*|}{$\begin{array}{c}\text { Volumetric shear } \\
\text { reinforcement ratio (\%) }\end{array}$} \\
\cline { 2 - 3 } & Actual & Balanced & 1.47 \\
\hline AF2T1 & 0.39 & 0.11 & 1.47 \\
BF3T1 & 0.59 & 0.36 & 1.47 \\
CF3T1 & 0.59 & 0.29 & 1.47 \\
DF2T1 & 0.39 & 0.26 & 1.47 \\
DF3T1 & 0.59 & 0.31 & 1.47 \\
DF4T1 & 0.85 & 0.30 & 3.57 \\
DF3T2 & 0.59 & 0.18 & 4.62 \\
DF3T3 & 0.59 & 0.18 & 3.57 \\
DS4T2 & 2.17 & 9.87 & \\
\hline
\end{tabular}
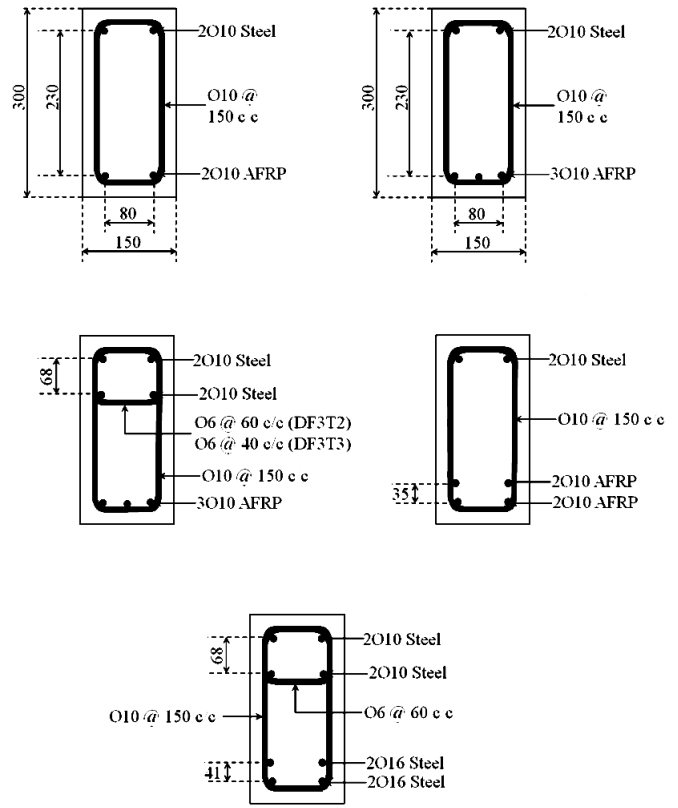

Fig. 1. Cross-sectional details of the test beams. 
Rashid et al. [14] reported that the $\varnothing 16, \varnothing 10$, and $\varnothing 6$ steel bars had average yield strengths of 466, 533, and $354 \mathrm{MPa}$, respectively, and the AFRP bars had a tensile strength of $1760 \mathrm{MPa}$ and an elastic modulus of $53 \mathrm{GPa}$. The concrete strength was obtained as $84.5 \mathrm{MPa}$ in beams DF2T1, DF3T1, DF4T1, DF3T2, DF3T3, and DS4T2; 42.8 MPa in beam AF2T1; 85.8 and 85.6 $\mathrm{MPa}$ in beam BF3T1 and beam CF3T1, respectively, from the cylinder tests.

1.2. Finite Element Model. Reinforced concrete structures are commonly analyzed using the finite element method through separated and distributive models. Separated models simulate the reinforcing bars using link or pipe elements, which are connected to the nodes of the concrete elements (Fig. 2a). In distributive models (Fig. 2b), on the other hand, reinforcement is introduced to the model by assigning number, position, angle, and reinforcement ratio to the reinforced material in each direction of the three dimensional space using the real parameters of the Solid65 element [24, 25, 30]. In other words, no additional elements are used for the reinforcement. Although separated models assume a perfect bond between the reinforced and reinforcing materials, these models were adopted in the present study since the studies in the literature [24, 30] indicated that FE analyses based on separated models provide closer estimates to the expeimental results.

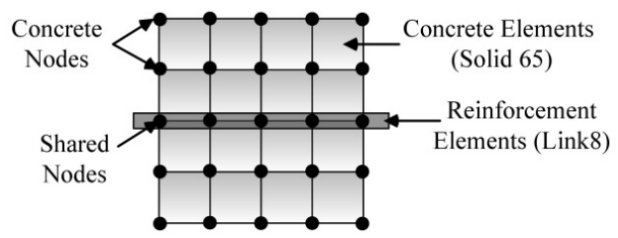

a

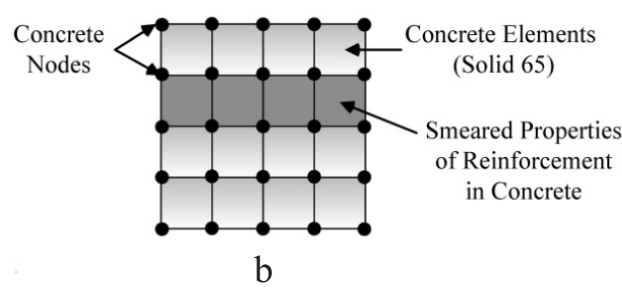

Fig. 2. Reinforcement modeling in FEA: (a) separated model; (b) distributive model.

\subsection{Material Models.}

1.3.1. Concrete. Two different concrete stress-strain models were used in the present study for the NSC and HSC beams. In the analytical calculations and numerical analysis of beam AF2T1, which had a concrete strength of $42.8 \mathrm{MPa}$, Todeschini et al. [35] stress-strain model was adapted, while Wee et al. [34] stress-strain model for HSC was used in rest of the beams, whose concrete strength values exceeded $80 \mathrm{MPa}$. The equations used in both stress-strain models are illustrated in Fig. 3. In the numerical analyses, concrete plasticity was modeled implementing multilinear isotropic hardening and using the values obtained from the stress-strain models. In multilinear isotropic hardening, the behavior of concrete in the three-dimensional space of the principal stresses is defined by the following equation based on von Mises criterion [36]: 


$$
\sigma_{y} \geq \sigma_{e}=\left[\frac{1}{2}\left[\left(\sigma_{1}-\sigma_{2}\right)^{2}+\left(\sigma_{2}-\sigma_{3}\right)^{2}+\left(\sigma_{3}-\sigma_{1}\right)^{2}\right]\right]^{1 / 2},
$$

where $\sigma_{e}$ is the equivalent stress, $\sigma_{1}, \sigma_{2}$, and $\sigma_{3}$ are the principal stresses, and $\sigma_{y}$ the threshold stress, which is the stress value at which a material passes from elastic state to plastic state. When the threshold stress is exceeded in concrete, the material is assumed to have a nonlinear behavior. In other words, the von Mises criterion is employed to differentiate between the linear and nonlinear types of material behavior.

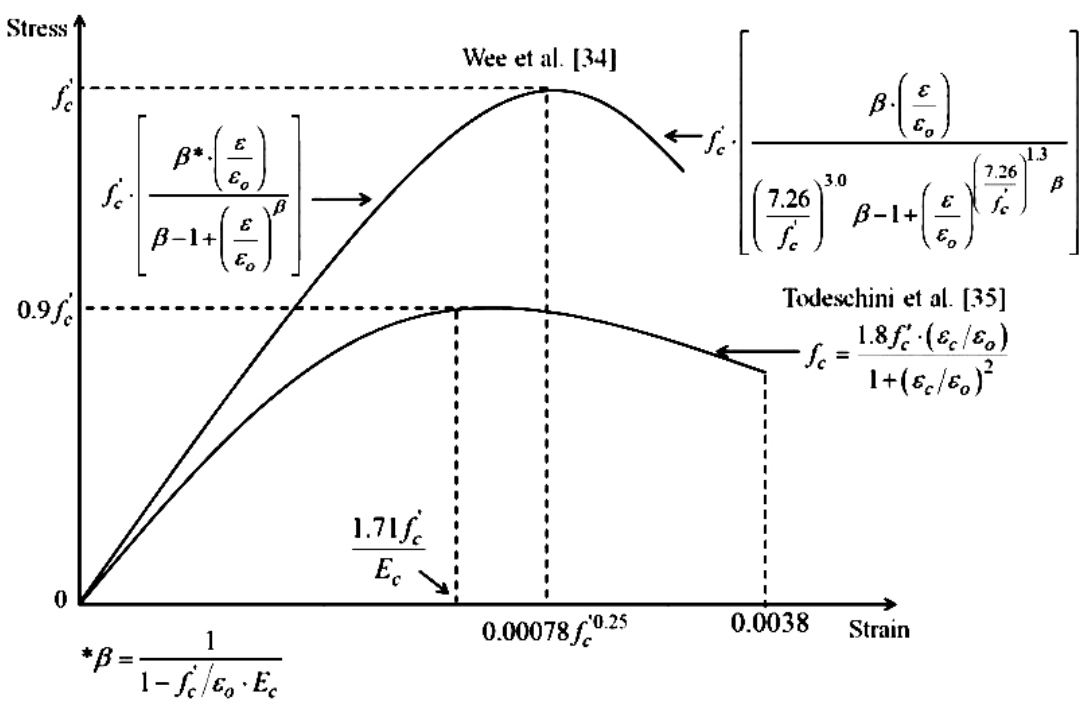

Fig. 3. Concrete stress-strain models.

1.3.2. Steel and FRP Reinforcing Bars. In the numerical and analytical studies, behavior of the steel rebars was idealized as bilinear isotropic based on von Mises yielding criteria. The AFRP bars were assumed to have a linear stress-strain relationship up to rupture. The discrete technique, which assigns bar or beam elements to the reinforcement, was implemented. In the models, Link8 elements corresponding to the reinforcing bars were connected to the concrete mesh nodes (Fig. 2a). Therefore, the concrete mesh shared the same nodes as the reinforcement mesh and both constituents occupied the same space in the model, preventing independent choice of the concrete mesh due to restriction by the location of reinforcement.

1.4. Cracking and Crushing of Solid65 Element. Solid65 element adopts the Willam-Warnke [37] model for the failure surface of concrete in a triaxial stress state. Willam-Warnke failure criterion is a five-parameter mathematical model applicable to regions of high compressive stresses, developed by the incorporation of two additional parameters to a previous three-parameter model applicable to regions of tensile or low compressive stresses. By the inclusion of the two parameters, the straight meridians in the model were transformed into smooth curved meridians. Close agreement of the values obtained from this model with the 
experimental data in the operating range, smooth, continuous, and convex failure surface, and the use of parameters attainable from standard test data makes the Willam-Warnke model advantageous over the other failure models [38].

In ANSYS, a Solid65 element reaches the crushing state and its stiffness nullifies when all of the principal stresses are compressive and the maximum principal compressive strain reaches the crushing strain. Solid65 element adopts the maximum tensile stress criterion (tension cutoff) for cracking of concrete in the presence of a principal tensile stress. Accordingly, smeared crack model allowing a maximum of three mutually perpendicular cracks at each Gaussian integral point is used when an element reaches the cracking state.

In ANSYS, the concrete material strength criterion data table includes the cracking and closure shear transfer coefficients, the uniaxial tensile and compressive strengths, the biaxial compressive strength, the confining pressure, the uniaxial and biaxial compressive strengths under confining pressure, and the tensile stress release coefficient. Usually, ANSYS only requires the first four parameters to be defined. In the present study, a value of 0.5 was used for the cracking shear transfer coefficient and a value of 0.9 for the closure shear transfer coefficient, based on the suggestions of the previous researchers [24]. The concrete cylinder strengths reported by Rashid et al. [14] were used as the uniaxial compressive strengths of the beams. The uniaxial tensile strengths were determined from uniaxial compressive strengths using the following equation given in ACI 318M-05 [16]:

$$
f_{r}=0.62 \sqrt{f_{c}^{\prime}}
$$

where $f_{r}$ is the modulus of rupture (tensile strength in bending) and $f_{c}^{\prime}$ the compressive strength of concrete. In order to accurately simulate the whole damage process of RC beams, the constitutive relation data table was also defined in ANSYS as well as the concrete material strength criterion data table. The values of the parameters used in the FEA of each specimen are tabulated in Table 2.

$\mathrm{T}$ a b 1 e 2

Values of the Parameters Used in the Concrete Material Strength Criterion Data Table in ANSYS

\begin{tabular}{||c|c|c|c|c||}
\hline \multirow{2}{*}{ Specimen } & \multicolumn{3}{|c||}{ Parameter } \\
\cline { 2 - 3 } & Shear transfer coefficient & $\begin{array}{c}\text { Uniaxial tensile } \\
\text { cracking stress (MPa) }\end{array}$ & $\begin{array}{c}\text { Uniaxial crushing } \\
\text { stress (MPa) }\end{array}$ \\
\cline { 2 - 4 } & Open crack & Closed crack & 4.06 & 42.8 \\
AF2T1 & 0.5 & 0.9 & 5.74 & 85.8 \\
BF3T1 & 0.5 & 0.9 & 5.74 & 85.6 \\
CF3T1 & 0.5 & 0.9 & 5.69 & 84.5 \\
DF2T1 & 0.5 & 0.9 & 5.69 & 84.5 \\
DF3T1 & 0.5 & 0.9 & 5.69 & 84.5 \\
DF4T1 & 0.5 & 0.9 & 5.69 & 84.5 \\
DF3T2 & 0.5 & 0.9 & 5.69 & 84.5 \\
DF3T3 & 0.5 & 0.9 & 5.69 & 84.5 \\
DS4T2 & 0.5 & 0.9 & \multicolumn{3}{|c||}{} \\
\hline
\end{tabular}


1.5. Nonlinear Solution in ANSYS. ANSYS uses hybrid method in nonlinear problem solving, which applies load steps using the incremental method and performs iterations using the Newton-Raphson method in each step. The convergence is forced in every load increment so that the equilibrium state becomes the eventual solution of the overall FE equations.

A rectangular mesh, which is more appropriate for the Solid65 element, was preferred in the present study. Each beam was divided into a total of 16875 rectangular prism shaped mesh elements. Two concentrated loads were applied to the upper surface of the beam, each at 18 nodal points. The loading and support conditions of the beams and the reinforcement details are illustrated in Figs. 4 and 5 , respectively.

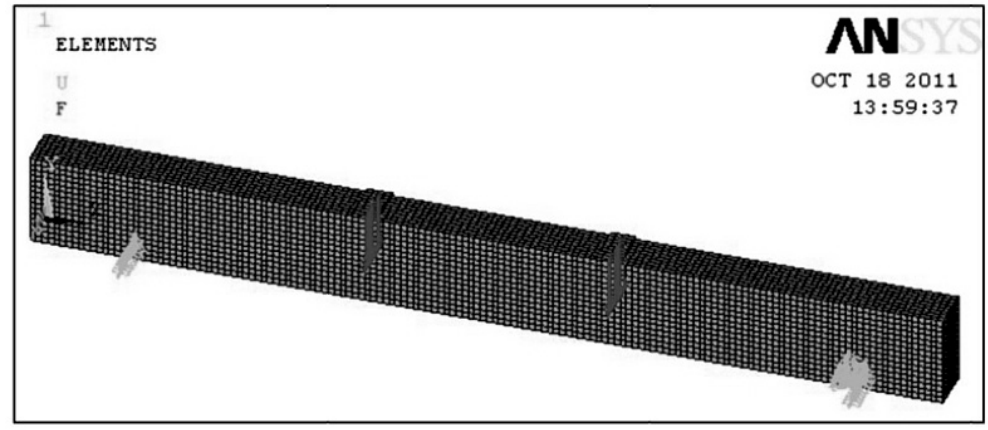

Fig. 4. Loading and support conditions in the FE model.

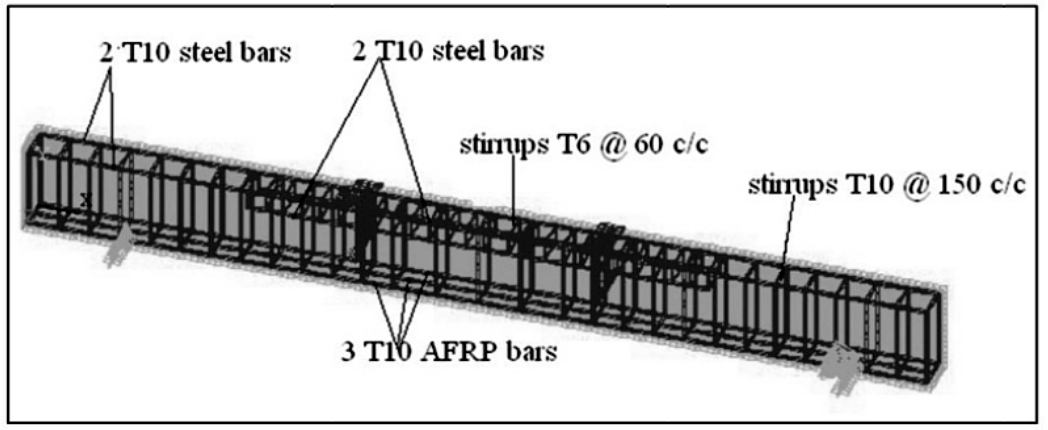

Fig. 5. Reinforcement details of specimen DF3T2 in the FE model.

\section{Results and Discussion.}

2.1. Failure Modes and Load-Deflection Behaviors. Rashid et al. [14] reported that their specimens failed in two distinct failure modes. All of the beams except BF3T1, DF2T1, and DF3T1 failed in flexure. In these specimens, an initial failure occurred once the unconfined cover concrete crushed. After this initial failure, the load-carrying capacities of the over-reinforced beams increased to a limited extent, after which a final failure occurred due to the crushing of the confined concrete inside the stirrups. The beams failing in flexure were severely cracked and had extensive deformations at failure (Fig. 6) as a result of the low elastic modulus of AFRP. The extensive cracking and deformations in the beams at failure were accurately estimated by the FEA, as indicated in Fig. 7. In beams BF3T1, DF2T1, and DF3T1, on the other hand, the failure was in a flexure-shear 


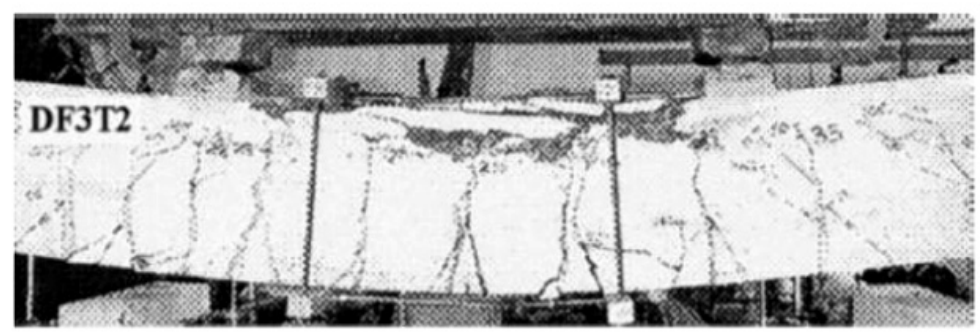

Fig. 6. Specimen DF3T2 at failure (from [14]).

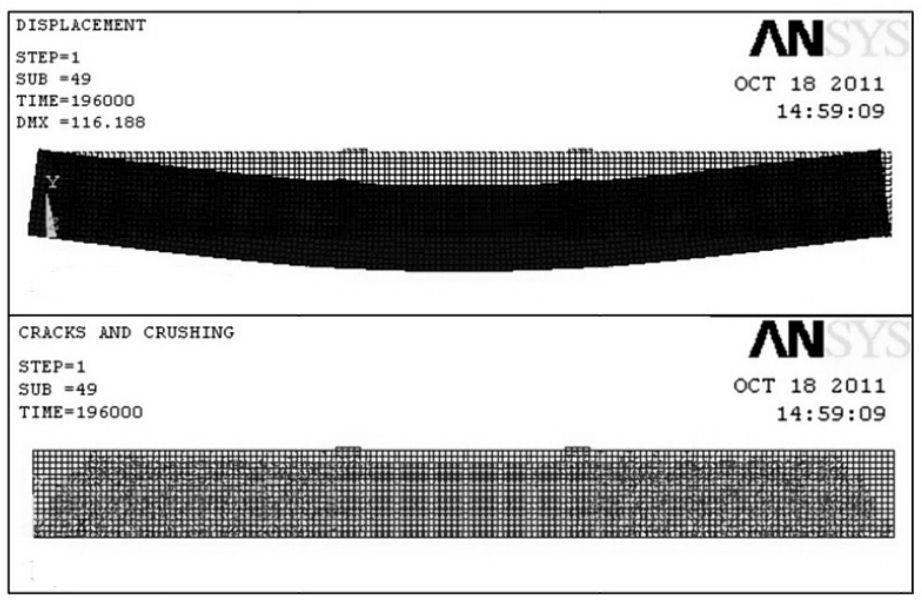

Fig. 7. Deformations and cracks in specimen DF3T2 at failure.

mode as a result of the formation of a diagonal tension crack through the compression zone causing the compression zone to cease to contribute to the shear resistance. Due to the limited dowel action in the FRP bars, the beams failed suddenly after the formation of this diagonal crack. Rashid et al. [14] reported that the amount of stirrups in BF3T1, DF2T1, and DF3T1 could not prevent this flexure-shear failure despite having a sufficient amount of shear reinforcement according to the ACI 318-99 [39] code requirements. In FEA, all of the specimens failed in a flexural mode and the specimens did not experience diagonal cracking, which may be attributed to the fail in estimating the low dowel action of the FRP bars in the analyses.

Figure 8 compares the experimental load-deflection curves of the beams with the analytical load-deflection curves obtained by using two different effective moment of inertia expressions [Eqs. (2) and (6)] and the numerical curves obtained from the FEA. In Fig. 8i, the effective moment of inertia expression [Eq. (1)] given in ACI 318M-05 [16] was used instead of the expression [Eq. (2)] given in ACI 440.1R-06 [4]. Equation (1) is applicable to concrete beams reinforced with steel bars. As shown in Fig. 8, the numerical analyses continued until the maximum load given by the program, so they did not include the tails of the curves beyond the ultimate loads, which are not of interest in the present study.

FRP-reinforced concrete beams have a distinct characteristic that differentiates them from the steel-reinforced concrete beams. Due to the low elastic modulus of the reinforcing material, a sudden drop in the stiffness of the beam 

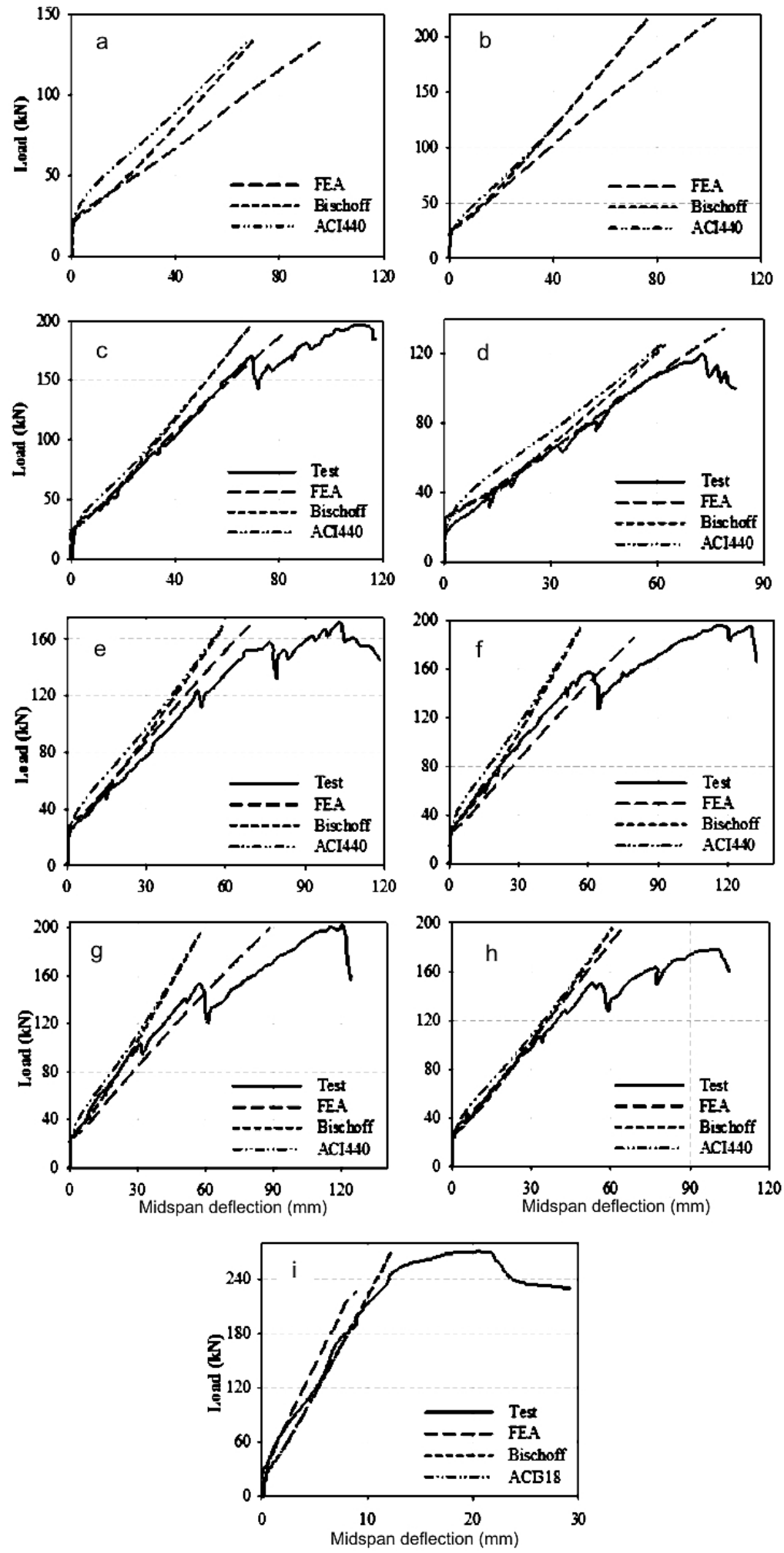

Fig. 8. Load-deflection curves of specimens AF2T1 (a), BF3T1 (b), CF3T1 (c), DF2T1 (d), DF3T1 (e), DF3T2 (f), DF3T3 (g), DF4T1 (h), and DS4T2 (i). 
takes place once the cover concrete outside the stirrups crushes. If the beam has a high amount of tension reinforcement, the load-carrying capacity of the beam continues increasing after this sudden drop, meaning that the beam possesses postcracking stiffness. If the beam has a low amount of tension reinforcement, the sudden drop in the rigidity due to the crushing of the cover concrete cannot be recovered and the beam fails. Figure 8 indicates that the recovery in the rigidity after the sudden drop took place in all beams except for DF2T1, which failed suddenly due to the low amount of tension reinforcement when the cover concrete crushed. The results of this study agreed with the findings of Lau and Pam [40], who found out that FRP RC beams should be designed over-reinforced so that they do not fail suddenly after cover concrete crushing.

It can be seen in Fig. 8 that the deflection estimates obtained from the FEA are in close agreement with the experimental results. As mentioned previously, some differences between the experimental and numerical curves arises due to the fact that the analysis programs cannot correctly estimate the sudden drop in the stiffness once the cover concrete crushes. FEA generally provided conservative deflection estimates up to the first peak in the load-deflection curve corresponding to the initiation of cover concrete crushing. However, the deflection estimates from the FEA do not remain on the conservative side beyond this peak. The analytical load-deflection curves were also in close agreement with the experimental ones at the initial stages of loading. As the applied load increases and the extent of flexural cracking in the beam increases, the differences between the analytical and experimental curves become large. In beam DS4T2 (Fig. 8i), the analytical and numerical curves can be seen to be in close agreement with the experimental curve almost up to the ultimate load since the degradation in the stiffness of the beam takes place gradually and no sudden drops in the stiffness takes place up to the proximity of the ultimate load. Nevertheless, the formation of new flexural cracks and the propagation of the existing cracks result in sudden drops in the stiffness of the FRP RC beams along the increasing portion of the curve due to the low elastic modulus of AFRP. FEA and analytical expressions fail to estimate these drops accurately, which result in unconservative deflection estimates in the further stages of loading. Finally, the load-deflection curves indicate that the effective moment of inertia expression proposed by Bischoff [18] estimates the load-deflection responses of FRP RC beams more accurately compared to the effective moment of inertia expression given in ACI 440.1R-06 [4].

2.2. Service-Load Deflections. Since the service-load deflections are controlled in the design of RC beams, the accuracy of the deflection estimates from FEA and analytical expressions under service loads need to be assessed. In the present study, the service moments of the beams were determined according to the compressive stress limitations given in EC2 [41], which limits the maximum compressive stress in a beam to $60 \%$ of the characteristic strength of concrete under the characteristic combination of loads and $45 \%$ of the characteristic strength for the quasi-permanent loading when linear creep needs to be taken into account. The service moments corresponding to these two stress limits and the deflection values corresponding to these service moments are tabulated in Tables 3 and 4 . The service moments can be seen to around 45 and $30 \%$ of the ultimate moments for the maximum compressive stress in the beam in the order of 60 and $45 \%$ of the 
$\mathrm{T}$ a b 1 e 3

Service Moments and Service-Load Deflections of the Beams at $0.6 f_{c}^{\prime}$

\begin{tabular}{|c|c|c|c|c|c|c|c|c|}
\hline \multirow[t]{2}{*}{ Beam } & \multirow{2}{*}{$\frac{M_{s}}{M_{u t}}$} & \multicolumn{4}{|c|}{ Midspan deflection (mm) } & \multirow{2}{*}{$\frac{\Delta_{F E A}}{\Delta_{\exp }}$} & \multirow{2}{*}{$\frac{\Delta_{A C I}}{\Delta_{\exp }}$} & \multirow{2}{*}{$\frac{\Delta_{a n}}{\Delta_{\text {exp }}}$} \\
\hline & & $\begin{array}{l}\text { Test } \\
\Delta_{\exp }\end{array}$ & $\begin{array}{r}\text { FEA } \\
\Delta_{F E A} \\
\end{array}$ & $\begin{array}{r}\mathrm{ACI} \\
\Delta_{A C I} \\
\end{array}$ & $\begin{array}{c}\text { Bischoff } \\
\Delta_{a n}\end{array}$ & & & \\
\hline CF3T1 & 0.40 & 22.30 & 22.28 & 19.65 & 22.29 & 1.00 & 0.88 & 1.00 \\
\hline DF2T1 & 0.44 & 21.85 & 25.38 & 16.17 & 22.53 & 1.16 & 0.74 & 1.03 \\
\hline DF3T1 & 0.42 & 23.95 & 20.48 & 15.87 & 20.01 & 0.86 & 0.66 & 0.84 \\
\hline DF4T1 & 0.46 & 17.75 & 17.72 & 14.95 & 19.07 & 1.00 & 0.84 & 1.07 \\
\hline DF3T2 & 0.41 & 16.25 & 19.57 & 10.46 & 15.56 & 1.20 & 0.64 & 0.96 \\
\hline DF3T3 & 0.42 & 14.71 & 20.29 & 12.06 & 16.30 & 1.38 & 0.82 & 1.11 \\
\hline DS4T2 & 0.67 & 8.01 & 6.51 & 8.17 & 8.10 & 0.81 & 1.02 & 1.01 \\
\hline & & & & & Mean & 1.06 & 0.68 & 1.04 \\
\hline & & & & & Stdev & 0.28 & 0.20 & 0.20 \\
\hline & & & & & $\% \mathrm{COV}$ & 27 & 30 & 19 \\
\hline
\end{tabular}

$\mathrm{T}$ a b 1 e 4

Service Moments and Service-Load Deflections of the Beams at $0.45 f_{c}^{\prime}$

\begin{tabular}{|c|c|c|c|c|c|c|c|c|}
\hline \multirow[t]{2}{*}{ Beam } & \multirow{2}{*}{$\frac{M_{s}}{M_{u t}}$} & \multicolumn{4}{|c|}{ Midspan deflection (mm) } & \multirow{2}{*}{$\frac{\Delta_{F E A}}{\Delta_{\exp }}$} & \multirow{2}{*}{$\frac{\Delta_{A C I}}{\Delta_{\exp }}$} & \multirow{2}{*}{$\frac{\Delta_{a n}}{\Delta_{\text {exp }}}$} \\
\hline & & $\begin{array}{l}\text { Test } \\
\Delta_{\exp }\end{array}$ & $\begin{array}{c}\text { FEA } \\
\Delta_{F E A}\end{array}$ & $\begin{array}{r}\mathrm{ACI} \\
\Delta_{A C I}\end{array}$ & $\begin{array}{c}\text { Bischoff } \\
\Delta_{a n}\end{array}$ & & & \\
\hline CF3T1 & 0.30 & 15.14 & 13.66 & 10.21 & 14.03 & 0.90 & 0.67 & 0.93 \\
\hline DF2T1 & 0.33 & 14.20 & 13.30 & 6.94 & 12.44 & 0.94 & 0.49 & 0.88 \\
\hline DF3T1 & 0.29 & 15.15 & 12.86 & 7.91 & 12.39 & 0.85 & 0.52 & 0.82 \\
\hline DF4T1 & 0.34 & 10.86 & 11.19 & 6.83 & 11.51 & 1.03 & 0.63 & 1.06 \\
\hline DF3T2 & 0.30 & 8.47 & 12.11 & 4.73 & 9.45 & 1.43 & 0.56 & 1.12 \\
\hline DF3T3 & 0.31 & 8.63 & 12.89 & 7.56 & 12.29 & 1.49 & 0.88 & 1.42 \\
\hline \multirow[t]{4}{*}{ DS4T2 } & 0.50 & 5.87 & 4.63 & 6.09 & 6.02 & 0.79 & 1.04 & 1.03 \\
\hline & & & & & Mean & 1.06 & 0.68 & 1.04 \\
\hline & & & & & Stdev & 0.28 & 0.20 & 0.20 \\
\hline & & & & & $\% \mathrm{COV}$ & 27 & 30 & 19 \\
\hline
\end{tabular}

concrete strength, respectively. Previous studies $[42,43]$ suggested that the service moment should be in the order of $35 \%$ of the ultimate moment in FRP RC beams, which approximately corresponds to a limit stress of $45 \%$ of the concrete strength. Tables 3 and 4 indicate that the deflection estimates from FEA and the expression proposed by Bischoff [18] are in close agreement with the experimental values at both service moment levels. The deflection estimates obtained using the effective moment expression in ACI 440.1R-06 [4] are significantly below the experimental values. Both FEA and the analytical expression of Bischoff [18] overestimate the experimental deflection values and provide conservative estimates while the estimates from the ACI 440.1R-06 [4] expression are on the unconservative side. In particular, the agreement of the analytical estimates from Bischoff's expression are remarkable with a mean value of the analytical to experimental deflection ratio close to unity at both service load levels. 
$\mathrm{T}$ a b 1 e 5

Ultimate Moments of the Beams

\begin{tabular}{|c|c|c|c|c|c|c|c|c|c|}
\hline \multirow[t]{2}{*}{ Beam } & \multicolumn{4}{|c|}{ Ultimate flexural moment $(\mathrm{kN} \cdot \mathrm{m})$} & \multirow{2}{*}{$\frac{M_{u f}}{M_{u t}}$} & \multirow{2}{*}{$\frac{M_{u c 1}}{M_{u t}}$} & \multirow{2}{*}{$\frac{M_{u c 2}}{M_{u t}}$} & \multirow{2}{*}{$\frac{M_{u c 2}}{M_{u f}}$} & \multirow{2}{*}{$\begin{array}{l}\text { Failure } \\
\text { mode }\end{array}$} \\
\hline & $\begin{array}{c}\text { Test } \\
\left(M_{u t}\right)\end{array}$ & $\begin{array}{c}\text { FEA } \\
\left(M_{u f}\right)\end{array}$ & $\begin{array}{c}\mathrm{ACI} \\
\left(M_{u c 1}\right)\end{array}$ & $\begin{array}{l}\text { Model } \\
\left(M_{u c 2}\right)\end{array}$ & & & & & \\
\hline $\mathrm{AF} 2 \mathrm{~T} 1$ & 44.17 & 54.00 & 45.35 & 41.23 & 1.22 & 1.03 & 0.93 & 0.76 & Flexure \\
\hline BF3T1 & 59.46 & 79.60 & 59.32 & 80.68 & 1.34 & 1.00 & 1.36 & 1.01 & Flex-shear \\
\hline CF3T1 & 67.21 & 79.60 & 59.31 & 73.95 & 1.18 & 0.88 & 1.10 & 0.93 & Flexure \\
\hline DF2T1 & 48.06 & 46.80 & 47.16 & 57.22 & 0.97 & 0.98 & 1.19 & 1.22 & Flex-shear \\
\hline DF3T1 & 62.77 & 79.60 & 58.88 & 76.24 & 1.27 & 0.94 & 1.21 & 0.96 & Flex-shear \\
\hline DF4T1 & 60.02 & 74.88 & 61.33 & 74.87 & 1.25 & 1.02 & 1.25 & 1.00 & Flexure \\
\hline DF3T2 & 62.41 & 77.76 & 56.78 & 72.04 & 1.25 & 0.91 & 1.15 & 0.93 & Flexure \\
\hline DF3T3 & 60.80 & 79.92 & 56.78 & 72.02 & 1.31 & 0.93 & 1.18 & 0.90 & Flexure \\
\hline \multirow[t]{4}{*}{ DS4T2 } & 107.20 & 84.00 & 91.19 & 96.20 & 0.78 & 0.85 & 0.90 & 1.15 & Flexure \\
\hline & & & & Mean & 1.18 & 0.95 & 1.14 & 0.98 & \\
\hline & & & & Stdev & 0.18 & 0.06 & 0.15 & 0.14 & \\
\hline & & & & $\% \mathrm{COV}$ & 15 & 7 & 13 & 14 & \\
\hline
\end{tabular}

2.3. Ultimate Moments. Table 5 compares the ultimate moment estimates obtained from FEA $\left(M_{u f}\right)$, the rectangular stress block method $\left(M_{u c 1}\right)$ of the ACI Codes $[4,16]$, and the concrete stress-strain models $\left(M_{u c 2}\right)$ with the experimental ultimate moments $\left(M_{u t}\right)$ reported by Rashid et al. [14]. The $M_{u c 2}$ values in the table were calculated using the Wee et al. [34] and Todeschini et al. [35] stress-strain models. The $M_{u f} / M_{u t}, M_{u c 1} / M_{u t}, M_{u c 2} / M_{u t}$, and $M_{u c 2} / M_{u f}$ moment ratios are also presented in the table with their means, standard deviations (StDev), and percent coefficients of variation (\%COV) for comparing the estimated values to the experimental ones. It can be seen that FEA and concrete stress-strain models generally overestimated the experimental values of the FRP RC beams and the moment estimates obtained from the rectangular stress block analysis provided closer agreement with the experimental values. The overestimation of the experimental values by FEA and the analytical model containing the concrete stress-strain models might be related to the reductions in the ultimate load-carrying capacities of the beams caused by the diagonal shear cracks resulting from the low dowel action of the AFRP bars. As previously mentioned, these diagonal cracks were not accurately estimated by FEA, so the numerical analyses yielded to higher ultimate moment estimates not subject to reductions from diagonal cracking. In the steel-reinforced beam (DS4T2), nonetheless, the numerical and analytical moment estimates were much below the experimental moment. The close agreement of the moment estimates from the concrete stress-strain models and FEA is also noteworthy.

Conclusions. A number of AFRP-reinforced concrete beams tested by Rashid et al. [14] were analyzed using the FEA program ANSYS [22]. The experimental load-deflection curves from the study of Rashid et al. [14] and the numerical curves from FEA were compared with the analytical curves obtained by using the effective moment of inertia expressions given in the ACI 318M-05 [16] and ACI 440.1R-06 [4] codes and the expression proposed by Bischoff [18]. The experimental, numerical, and analytical deflection values at two service load levels 
given by the EC2 [41] code for the characteristic combination of loads and for the quasi-permanent loading were also compared. Finally, the ultimate flexural capacities of the beams were determined analytically using the rectangular stress block analysis [4, 16] and the stress-strain models proposed by Wee et al. [34] and Todeschini et al. [35] for HSC and NSC, respectively and these analytical values were compared with the experimental and numerical ultimate moments of the specimens. Based on the FEA of the specimens and comparison of the experimental, numerical, and analytical results, the following conclusions were drawn:

1. In steel-reinforced concrete beams, both FEA and analytical effective moment of inertia expressions provide conservative deflection estimates in close agreement with the experimental values. In FRP RC beams, FEA accurately estimates the deflection values up to the first peak in the load-deflection curve corresponding to the crushing of the cover concrete. Beyond the first peak, the significant reduction in the stiffness due to the low elastic modulus of AFRP causes the numerical and analytical deflection estimates to be smaller than the experimental values. The deflection estimates from FEA and the effective moment of inertia proposed by Bischoff [18] are in a close agreement with the experimental values at service load levels, while the ACI 440.1R-06 [4] effective moment of inertia expression yields unconservative deflection estimates.

2. The analytical ultimate flexural moment estimates based on the rectangular stress block method of the ACI Codes $[4,16]$ are in close agreement with the experimental ultimate moment values. The analytical estimates obtained using the concrete stress-strain models were found to be in close agreement with the ultimate moment values from FEA, which may be attributed to the reductions in the moment capacities of the beams due to formation of diagonal shear cracks prior to reaching the ultimate load levels. The rectangular stress block analysis can be said to yield conservative ultimate moment estimates even in the presence of diagonal shear cracks at loads below the ultimate flexural capacity.

3. The severe cracking and extensive deformations in the AFRP RC beams due to the low elastic modulus of AFRP were correctly estimated by FEA. The failure of some specimens in a flexure-shear mode rather than a pure flexure mode due to the low dowel action in the FRP bars was not accurately estimated by FEA, which may be attributed to the shear transfer coefficient values used in the FE model. Further research on the evaluation of the shear transfer coefficient values that need to be used in FRP RC beams will be necessary for the accurate estimation of the shear-flexure failures in FRP RC beams.

\section{Резюме}

Представлено результати аналітичних і чисельних досліджень, метою яких $\epsilon$ визначення згинальних характеристик залізобетонних балок, зміцнених полімерними стрижнями 3 армованих волокон. За допомогою спеціального методу скінченних елементів, що включає різні елементи для процесів бетонування й армування, проаналізовано залізобетонні балки, армовані полімерними стрижнямі. Для оцінки характеристик прогину під дією навантаження і прогину балки під дією робочого навантаження використовували два різних рівняння ефективного моменту інерції. Значення прогину залізобетонних балок із 
полімерними стрижнями під дією робочого навантаження, отримані скінченноелементним методом, добре зіставляються зі значеннями з рівнянь моменту інерції. Числові значення руйнівного моменту також добре узгоджуються 3 аналітичними значеннями, отриманими по моделі залежності деформації від напруження для бетону. Для консервативної оцінки прогину представлено дані чисельного аналізу, які майже не спрогнозували раптове зменшення показника жорсткості при згині залізобетонних балок із полімерними стрижнями внаслідок руйнування захисного шару бетону.

1. A. C. Berg, L. C. Bank, M. G. Oliva, and J. S. Russell, "Construction and cost analysis of an FRP reinforced concrete bridge deck," Constr. Build. Mater., 20, 515-526 (2006).

2. E. El-Salakawy, B. Benmokrane, A. El-Ragaby, and D. Nadeau, "Field investigation on the first bridge deck slab reinforced with glass FRP bars constructed in Canada," ASCE J. Compos. Constr., 9, 470-479 (2005).

3. B. Benmokrane, E. El-Salakawy, S. El-Gamal, and S. Goulet, "Construction and testing of an innovative concrete bridge deck totally reinforced with glass FRP bars: Val-Alain bridge on highway 20 east," ASCE J. Bridge Eng., 12, 632-645 (2007).

4. ACI 440.1R-06. ACI Committee 440 Guide for the Design and Construction of Concrete Reinforced with FRP Bars, American Concrete Institute, Farmington Hills, Michigan (2006).

5. CSA Standard S806-02: Design and Construction of Building Component with Fiber-Reinforced Polymers, Canadian Standards Association, Toronto, Ontario, Canada (2002).

6. Japan Society of Civil Engineers Recommendation for Design and Construction of Concrete Structures Using Continuous Fiber Reinforcing Materials, Concrete Engineering Series No. 23, Research Committee on Continuous Fiber Reinforced Material, Tokyo, Japan (1997).

7. S. S. Faza and H. V. S. Ganga Rao, "Theoretical and experimental correlation of behavior of concrete beams reinforced with fiber reinforced plastic rebars," SP-138, ACI, Farmington Hills, Michigan (1993).

8. B. Benmokrane, O. Chaallal, and R. Masmoudi, "Flexural response of concrete beams reinforced with FRP reinforcing bars," ACI Struct. J., 93, 46-55 (1996).

9. D. Gao, B. Benmokrane, and R. Masmoudi, "A calculating method of flexural properties of FRP-reinforced concrete beam. Part 1: Crack width and deflection," Technical Report, Department of Civil Engineering, University of Sherbrooke, Sherbrooke, Quebec, Canada (1998).

10. M. Theriault and B. Benmokrane, "Effects of FRP reinforcement ratio and concrete strength on the flexural behavior of concrete beams," $A S C E J$. Compos. Constr., 2, 7-16 (1998).

11. R. Masmoudi, M. Theriault, and B. Benmokrane, "Flexural behavior of concrete beams reinforced with deformed fiber reinforced plastic reinforcing rods," ACI Struct. J., 95, 665-676 (1998). 
12. H. A. Toutanji and M. Saafi, "Flexural behavior of concrete beams reinforced with glass fiber-reinforced polymer (GFRP) bars," ACI Struct. J., 97, 712-719 (2000).

13. J. R. Yost, S. P. Gross, and D. W. Dinehart, "Effective moment of inertia for glass fiber-reinforced polymer-reinforced concrete beams," ACI Struct. J., 100, 732-739 (2003).

14. M. A. Rashid, M. A. Mansur, and P. Paramasivam, "Behavior of aramid fiber-reinforced polymer reinforced high strength concrete beams under bending," ASCE J. Compos. Constr., 9, 117-127 (2005).

15. H. Vogel and D. Svecova, "New approach for estimating the deflection of beams reinforced with FRP reinforcement," ASCE J. Compos. Constr., 12, 579-587 (2008).

16. ACI 318M-05. Building Code Requirements for Structural Concrete and Commentary, American Concrete Institute, Farmington Hills, Michigan (2005).

17. D. E. Branson, "Instantaneous and time-dependent deflections of simple and continuous reinforced concrete beams," HPR Report No. 7, Part 1, Alabama Highway Department, Bureau of Public Roads, Alabama (1965).

18. P. H. Bischoff, "Reevaluation of deflection prediction for concrete beams reinforced with steel and fiber reinforced polymer bars," ASCE J. Struct. Eng., 131, 752-762 (2005).

19. P. H. Bischoff, "Rational model for calculating deflection of reinforced concrete beams and slabs," Can. J. Civ. Eng., 34, 992-1002 (2007).

20. Comite Euro-International Du Beton. CEB-FIP Model Code 1990: Design Code, Thomas Telford, London (1993).

21. P. H. Bischoff and A. Scanlon, "Effective moment of inertia for calculating deflections of concrete members containing steel reinforcement and fiberreinforced polymer reinforcement," ACI Struct. J., 104, 68-75 (2007).

22. ANSYS User's Manual Version 10.0, Swanson Analysis Systems Inc., Houston, USA (2006).

23. A. Arnesen, S. I. Sorensen, and P. G. Bergan, "Nonlinear analysis of reinforced concrete," Comput. Struct., 12, 571-579 (1980).

24. A. F. Barbosa and G. O. Riberio, "Analysis of reinforced concrete structures using ANSYS nonlinear concrete model," Comput. Mech., 1, 1-7 (2004).

25. I. Kalkan and A. Buyukkaragoz, "A numerical and analytical study on distortional buckling of doubly-symmetric steel I-beams," J. Constr. Steel Res., 70, 289-297 (2012).

26. E. Ellobody and B. Young, "Nonlinear analysis of concrete filled steel SHS and RHS columns," Thin Walled Struct., 44, 919-930 (2006).

27. K. F. Faherty, An Analysis of a Reinforced and a Prestressed Concrete Beam by Finite Element Method, Ph.D. Dissertation, University of Iowa (1972).

28. P. Fanning, "Nonlinear models of reinforced and post-tensioned concrete beams," Elect. J. Struct. Eng., 2, 111-119 (2001). 
29. Y. Hemmaty, G. De Roeck, and L. Vandewalle, "Finite element modelling of corner joints in reinforced concrete frames," in: Proc. of Int. Conf. Concrete 2000, Economic and Durable Construction through Excellence, Dundee, UK (1993), pp. 465-472.

30. D. I. Kachlakev, T. Miller, S. Yim, et al., "Finite element modelling of reinforced concrete structures strengthened with FRP laminates," Final Report SPR316, Oregon Department of Transportation Research Group (2001).

31. M. Ozcan, A. Bayraktar, A. Sahin, et al., "Experimental and finite element analysis on the steel fiber reinforced concrete (SFRC) beams ultimate behavior," Constr. Build. Mater., 23, 1064-1077 (2009).

32. H. Pham, R. Al-Mahaidi, and V. Sauma, "Modelling of CFRP concrete bond using smeared and discrete cracks," Compos. Struct., 75, 145-150 (2006).

33. L. U. Xinzheng and J. Jianjing, "Analysis for concrete structure under complex stress condition with Solid65 FEA element of ANSYS," Build. Struct., 33, 22-24 (2003).

34. T. H. Wee, M. S. Chin, and M. A. Mansur, "Stress-strain relationship of high strength concrete in compression," ASCE J. Mater. Civ. Eng., 8, 70-76 (1996).

35. C. E. Todeschini, A. C. Bianchini, and C. E. Kesler, "Behavior of concrete columns reinforced with high strength steels," ACI J. Proc., 61, 704-716 (1964).

36. A. Buyukkaragoz and A. Arslan, "The effect of steel plates with shear studs for weak column-strong beam connections in the reinforced concrete structures under earthquake effect," Strain, 47, 393-411 (2011).

37. K. J. Willam and E. P. Warnke, "Constitutive model for triaxial behaviour of concrete," in: Proc. of Concrete Structures Subjected to Triaxial Stresses (International Association of Bridge and Structural Engineering Conference), Bergamo, Italy (1974), pp. 174-191.

38. A. J. Wolanski, Flexural Behavior of Reinforced and Prestressed Concrete Beams Using Finite Element Analysis, M.S. Thesis, Marquette University, Milwaukee, Wisconsin. (2004).

39. ACI 318-99. Building Code Requirements for Structural Concrete and Commentary (ACI 318R-99), American Concrete Institute, Detroit (1999).

40. D. Lau and H. J. Pam, "Experimental study of hybrid FRP reinforced concrete beams," Eng. Struct., 32, 3857-3865 (2010).

41. Comite Europeen de Normalisation. Eurocode 2: Design of Concrete Structures - Part 1-1: General Rules and Rules for Buildings (EN 1992-1-1: 2004), Comite Europeen de Normalisation (CEN), Brussels, Belgium, (2004).

42. S. H. Alsayed, Y. A. Al-Salloum, and T. H. Almusallam, "Performance of glass fiber reinforced plastic bars as a reinforcing material for concrete structures," Composites Part B, 31, 555-567 (2000).

43. M. M. Rafi, A. Nadjai, F. Ali, and D. Talamona, "Aspects of behaviour of CFRP reinforced concrete beams in bending," Constr. Build. Mater., 22, 277-285 (2008). 